\title{
女性高齡者における床からの立ち上がり動作パターンの分類と 身体機能の比較
}

\section{Classification of patterns of standing-up movement from the floor and comparison of physical functions in elderly females}

\author{
岩瀬弘明 ${ }^{12)}$ 村田 伸 ${ }^{3)}$ 宮 崎 純 弥 ${ }^{4}$ \\ 大田尾 浩5) 堀 江 淳 ${ }^{3)}$ \\ HIROAKI IWASE ${ }^{12)}$, SHIN MURATA ${ }^{3)}$, JUNYA MiYAZAKI ${ }^{4)}$, \\ HIROSHI OTAO ${ }^{5)}$, JUN HORIE ${ }^{3)}$
}

\begin{abstract}
要旨 : 本研究の目的は, 女性高齢者の背臥位からの立ち上がり動作パターンを分類し, 各 パターン別に年齢，体格，身体機能を比較することである。対象は，60歳以上の女性高齢 者168名とした。背臥位からの立ち上がり動作パターンを分類し，パターン別に年齢，BMI， 握力，上体起こし，長座体前屈距離，片足立ち保持時間，6分間歩行，足把持力，大腿四 頭筋筋力 , 歩行時間，Timed Up and Go test を一元配置分散分析により比較した。背臥位 からの立ち上がり動作は，(1)両手両足を床につけた高這い位を経て立ち上がるパターン， (2)片膝立ちを経て立ち上がるパターン , (3)しゃがみ位から立ち上がるパターンの3つに分 類され，各パターンの全ての測定值に有意差は認められなかった。女性高齢者の背臥位か らの立ち上がり動作パターンは , 年齡や体格 , 筋力やバランス能力といった各種身体機能 的な特徵の影響を受けるとは言い切れないことが示唆された。
\end{abstract}

キーワード：女性高齢者，床からの立ち上がり動作，身体機能

\begin{abstract}
The purpose of this study was to classify patterns of standing-up movement from a supine position in elderly females, and compare the age, sex, and physical functions between the classified groups. Subjects were 168 females, aged over 60 years old. Patterns of standing-up movement from a supine position were classified, and the age, body mass index, grip strength, raising the upper body, sit-and-reach distance, one leg standing time, 6 minutes walking distance, foot-gripping strength, quadriceps femoris strength, walking time, and the timed up-and-go test were compared between the classified groups with one-way ANOVA. Patterns of standing-up movement from a supine position were classified into three categories: 1) standing up from a position in which both hands and feet are on the floor and both legs are straight, 2) standing up from a position in which
\end{abstract}

\footnotetext{
受付日：2011年 5 月18日，採択日：2011年 6 月 7 日

1 ) 介護老人保健施設 ふふれあいの里道海 : 福岡県大川市大字道海島861 († 831- 0007) TEL0944 880800 Geriatric Health Services Facility Fureainosato Doukai:861,Doukaijima, Ookawa-city, Fukuoka 831-0007, Japan. TEL+81944-88-0800

2 ) 西九州大学大学院 健康福祉学研究科 Graduate School of Health and Social Welfare Science, Nishikyushu University

3 ) 西九州大学 リハビリテーション学部 Faculty of Rehabilitation Science, Nishikyushu University

4 ) 目白大学 保健医療学部理学療法学科 Department of Physical Therapy, Faculty of Health Sciences, Mejiro University

5 ) 県立広島大学 保健福祉学部理学療法学科 Faculty of Health and Welfare, Prefectural University of Hiroshima
} 
one knee is on the floor, and 3) standing up from a squatting position. There was no significant difference between the groups regarding all measurements. Therefore, it was suggested that patterns of standing-up movement from a supine position in elderly females are not necessarily influenced by physical functions (e.g., the age, body type, muscle strength, and balancing ability).

Key words: elderly females, standing-up movement from the floor, physical function

\section{I . 緒 言}

床からの立ち上がり動作は，日常生活活動を遂行す る上で必要不可欠な基本動作である。この動作は, 脳 血管障害などの中枢神経疾患, 骨折などの運動器疾患, 加齢や長期臥症による全身の運動機能低下など樣々な 原因によって困難となる。これまでの研究により，床 からの立ち上がり動作は, 脳血管障害後の片麻痺患 者 $^{1-3)}$, 下肢筋力が低下した高齢者，股関節や膝関節 に関節可動域制限がある者 ${ }^{4}$ にとって，基本動作のな かでも比較的難易度の高い動作であると言われている。 理学療法は，身体に障害を有するものに対して，基本 動作能力の回復を目的として行われる。光のため, 姿 勢変換に関わる動作を理解し，床からの立ち上がり動 作パターンと身体機能の関係を分析することの意義は 大きい。

背臥位からの立ち上がり動作は，背臥位から立位へ の姿勢変化により，重心位置が低く支持基底面が広く 安定した状態から，重心位置が高く支持基底面が狭い 相対的に不安定な状態へと変化する。背臥位からの立 ち上がり動作を評価する方法は，背臥位から立ち上が る動作の過程を分析する方法 ${ }^{5-8}$ と, 背臥位から立ち 上がるまでの所要時間を測定する方法 ${ }^{900}$ がある。

背臥位から立ち上がる動作の過程を分析する方法は， Schaltenbrand ${ }^{5)}, \mathrm{McGraw}^{6}{ }^{6}$,Milani-Comparetti ら ${ }^{78)}$ によっ て, 幼少児を対象に始められ, 背臥位からの立ち上が り動作パターンは, 年令の増加とともに推移していく ことが報告されている。さらに , 背臥位からの立ち上 がり動作パターンはいくつかの類型が提案 ${ }^{11}$ 12) れれ， 幼児期にはよりエネルギー効率が高く経済的な動作パ ターンへ変化していくものの，加齢に伴い幼児期の発 達過程と逆行する動作パターンへと変化していくとさ れている ${ }^{10.13)}$ 。しかし，高齢者を対象とした先行研究 は，筆者らの探しうる範囲では星ら ${ }^{100}$ の報告のみであ り，被験者の数は40代22名，50代19名，60代28名，70 代43名，80代14名であり，高齢者数が少ない。また， 背臥位からの立ち上がり動作パターンと，10m歩行， $3 \mathrm{~m}$ 椅子間歩行の関係を検討しているが, 統計学的に 有意差は認められていない。この他, 対象者を高齢者
に絞らずとも，先行研究において，立ち上がり動作パ ターンと身体機能の関係について言及しているものは， 筆者らの探しうる範囲では見つからず，加龄に伴う変 化については十分に明らかにされていない。

以上のことから，高齢者における背臥位からの立ち 上がり動作パターンと身体機能との関係について十分 に検討されていない。弚こで本研究は, 地域在住の女 性高齢者を対象に, 床からの立ち上がり動作パターン を類型化し，乥れ光れの立ち上がり動作パターンの身 体機能的な特徵を明らかにするために，パターン別に 各種身体機能を比較した。

\section{II. 対象と方法}

1. 対 象

$\mathrm{F}$ 町に在住し，町主催の健康支援事業に参加した60 歳以上の女性高齢者178名を対象とした。兴の際行っ た認知機能検査で, 重度の認知症が認められないこと (Mini-Mental State Examination; MMSE で20点以上), および背臥位からの立ち上がり動作が行えることの条 件を満たした168名 (平均年齢74 2士 6 . 歳, 平均身長 $1468 \pm 118 \mathrm{~cm}$, 平均体重50 $8 \pm 9.0 \mathrm{~kg})$ を分析対象と した。対象者は自家用車や自転車，あるいは徒歩によっ て自ら調査に参加できる程度に自立した高齢者であり， 要介護認定を受けている者, および脳血管障害や関節 リウマチなどによる典型的な身体障害を有する者はい なかった。

なお, 対象者には研究の趣旨と内容, 得られたデー 夕は研究の目的以外には使用しないこと,および個人 情報の漏洩に注意することについて説明し，理解を得 た上て協力を求めた。また，研究への参加は自由意志 であり，被験者にならなくても不利益にならないこと を口答と書面で説明し，書面にて同意を得た後に研究 を開始した。

\section{2. 方 法}

被験者には運動のしやすい服装で, 裸足になっても らい, 畳の上で背臥位をとらせた。背臥位の姿勢は両 上肢を体側に位置させ，両下肢の踵を付ける姿勢，い 
わゆる“気をつけ”の姿勢とした。測定者は被験者の 頭側に位置して「用意, 始め」という測定開始の合図 を行った。「始め」と同時に，測定者はデジタルストッ プウォッチ (HS 70W：CASIO 社製) をスタートし， 被験者にできる限り速く立ち上がらせた。被験者の立 ち上がり動作への影響を防ぐために，事前に十分な説 明と練習を行わせ，立ち上がり動作方法の指示やデモ ンストレーションは行わず, 被験者が最も行いやすい 方法とした。被験者が立ち上がって静止立位となった ときにデジタルストップウォッチを停止した。なお， 立ち上がった姿勢は, 両上肢を体側に位置させ，両下
肢の踵を付ける姿勢，いわゆる“気をつけ”の姿勢と した。静止立位の判定は，(1)測定終了肢位である“気 をつけ”となること，(2)頭部・体幹・両上肢の極端な 動摇がないこと，(3)バランスを保持するための足関節 底背屈運動はわずかで, 床に足底が完全に接地してい ること, とした。測定は 2 回連続して行い, 弚の最速 值 $(\mathrm{sec})$ を解析に用いた。立ち上がり時に足底が滑っ たときや，上記(1)〜3の姿勢がとれなかった場合，測 定終了までの間に観察上, 大きく姿勢を修正した場合 には再測定を行った。

また , 背臥位からの立ち上がり動作は, 被験者が背

1 ) 両手両足を床につけた高這い位を経て立ち上がるパターン (Pパターン)

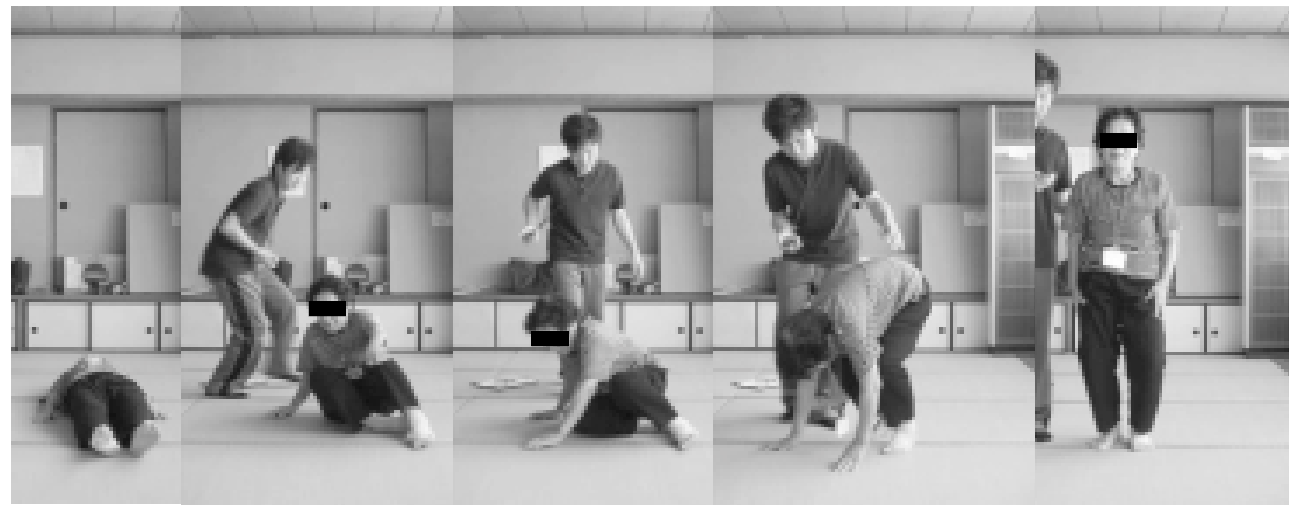

2 ) 片膝立ちを経て立ち上がるパターン ( $\mathrm{K}$ パターン)

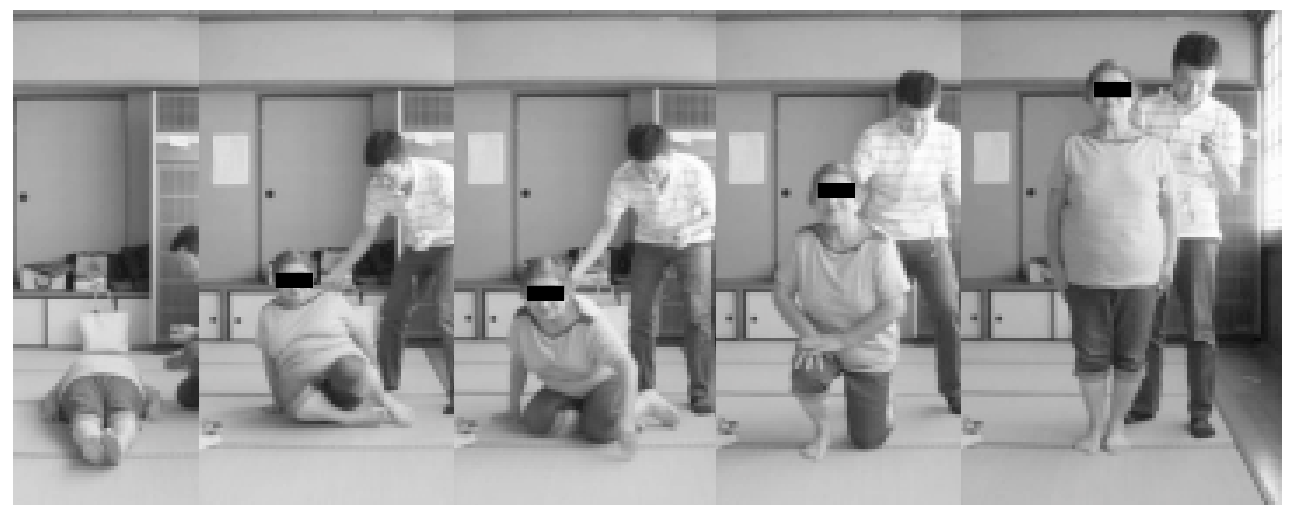

3) しゃがみ位から立ち上がるパターン ( $\mathrm{S}$ パターン)

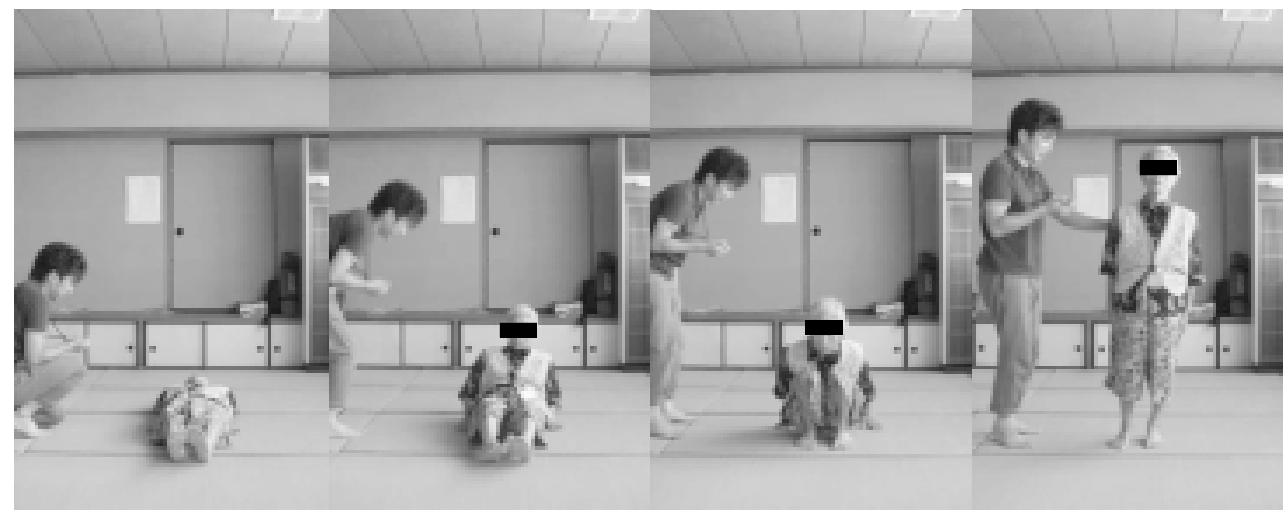

図 1 背臥位からの立ち上がり動作パターン 
臥位となった足側にデジタルビデオカメラを設置して 撮影した。デジタルビデオカメラの設置は, 課題視野 全体が納まるよう三脚を用いてレンズ高の調整を行っ た。取得した録画画像は, パソコンのディスプレイ上 で観察し, 必要に応じて静止・再生を繰り返しながら 動作パターンの分類を行った。

なお , 背臥位からの立ち上がり動作パターンの分類 方法は $\mathrm{McGraw}^{6}$ の報告，ならびに Milani-Comparetti

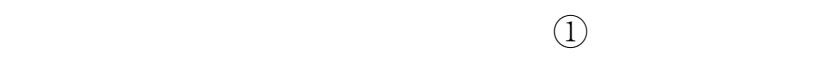
つけた高這い位を経て立ち上がるパターン(plantigrade pattern : 以下，Pパターン), (2)片膝立ちを経て立ち 上がるパターン (half-kneeling pattern : 以下，Kパター ン)，(3)しゃがみ位から立ち上がるパターン (squatting pattern : 以下, S パターン) の3つのパターンに分類 した (図 1 )。

身体機能の測定項目は，握力，上体起こし，長座体 前屈距離，片足立ち保持時間，6 分間歩行 (6MD)， 足把持力, 大腿四頭筋筋力, 歩行時間, Timed Up and Go test (TUG) を評価した。

握力の測定には, デジタル式握力計 (竹井機器工業 製) を使用した。測定姿位は立位で, 左右の上肢を体 側に垂らした状態で最大握力を左右とも 2 回測定し， 谷の最大値 $(\mathrm{kg})$ を代表值とした。

上体起こしは, 文部科学省高齢者用新体力テスト ${ }^{14)}$ に示された方法に従い，背臥位で両腕を胸の前で組み， 両膝を屈曲90度に保持した姿勢から, 両肘が両大腿部 に接触するまで上体を起こすように指示した。弚の際， 検者は被験者の両下腿部をしつかり固定して上体起こ しを補助した。なお，両肘が両大腿部に接触するまで 上体を起こせれば可能, 起こせなければ不可能と判定 した。

長座体前屈距離はデジタル式長座体前屈測定器（竹 井機器工業製) を用いて 2 回測定し, 光の最長距離 (cm) を採用した。

片足立ち保持時間の測定は，開眼片足立ち位で姿勢 保持できる時間について，120秒を上限としてデジタ ルストップウォッチを用いて測定した。この際, 被験 者には裸足になること, 両上肢はかるく体側につける こと， $2 \mathrm{~m}$ 前方の視線と同じ高さの点を注視すること を条件に測定を行った。

$6 \mathrm{MD}$ は， 1 周30mの室内スペースを利用し，6 分 間にできる限り長い距離を歩くよう指示し，弚の歩行 距離を $1 \mathrm{~m}$ 単位で測定した。

足把持力は，村田ら ${ }^{15}$ が作成したヤガミ社製ひずみ
ゲージを使用した足把持力測定器で測定した。なお， 得られた測定値の再現性や有用性については既に確認 されている ${ }^{16)}$ 。測定は，被験者の測定姿位を端座位， 膝関節を90度屈曲した状態で実施した。測定に際して， 予め母指と第 5 指の末節骨, 第 2 指から第 5 指の中節 骨が足指把持バーにかかるように，足部調節ダイヤル で調節し，把持バーを足指でしつかりと把持できるこ とを確認した。さらに，測定值の再現性を高める目的 で, 足部調節目盛りを取り付けた。測定は, 測定方法 を十分に習得させた後, 左右 2 回ずつ測定し, 弚の最 大值を足把持力值 $(\mathrm{kg})$ として採用した。

大腿四頭筋筋力は, ハンドヘルドダイナモメーター （アニマ社製等尺性筋力測定装置 $\mu$ Tas F 1) を用い， 被験者を坐位, 膝関節90度屈曲位として左右を 2 回測 定して，光の最大筋力 $(\mathrm{kg})$ を代表値とした。

歩行時間の測定は, 平地 $11 \mathrm{~m}$ を最速歩行してもらい， 中間の $5 \mathrm{~m}$ を測定区間として所要時間をデジタルス トップウォッチで計測した。測定は 2 回連続して行い， その最速値 ( sec) を代表值とした。

TUG は, 高さ40cmの肘掛けのないパイプ椅子に腰 掛けた姿勢から， $3 \mathrm{~m}$ 前方のポールを回って着座する までの時間をデジタルストップウォッチで計測した。 測定は 2 回連続して行い, 弚の最短時間 ( $\mathrm{sec}$ )を代表 值とした。原法17では「楽な速さ」で歩行するが，本 研究では最大努力で行ってもらい, 測定時の心理状態 や教示の解採の違いによる影響18 を排除した。

統計処理は，背臥位からの立ち上がり動作を動作パ ターン別に分類した 3 群と，体格と年齢の影響を考慮 し, 身長と体重から算出 (体重 $(\mathrm{kg}) \div$ 身長 $\left.(\mathrm{m})^{2}{ }^{2}\right)$ した Body Mass Index (BMI)，年齢，各身体機能（握 力, 上体起こし, 長座体前屈距離, 片足立ち保持時間, $6 \mathrm{MD}$, 足把持力, 大腿四頭筋筋力, 歩行時間, TUG) を一元配置分散分析で比較した。

なお，統計解析には SAS 社製 StatView5 .0を用い， 有意水準を $5 \%$ 末満とした。

\section{III. 結 果}

表 1 に被験者168名の各測定項目の平均值と標準偏 差を各パターン別に示した。P パターンをとる者は168 名中41名 $(24.4 \%), \mathrm{K}$ パターンをとる者は49名 (29 2\%)，S パターンをとる者は78名 (46 4\%) で あった。弚れら 3 群間の年齢, BMI, 各身体機能を比 較すると，年齢 $(\mathrm{F}=112, \mathrm{p}=0.33), \mathrm{BMI}(\mathrm{F}=1.68$ ， $\mathrm{p}=0$ 19) , 握力 $(\mathrm{F}=017, \mathrm{p}=0$ 84) , 上体起こし $(\mathrm{F}$ 
表1 各測定項目の平均値と標準偏差 $(\mathrm{n}=168)$

\begin{tabular}{|c|c|c|c|c|c|}
\hline & $\begin{array}{c}\mathrm{P} \text { パターン } \\
\mathrm{n}=41\end{array}$ & $\begin{array}{c}\mathrm{K} \text { パターン } \\
\mathrm{n}=49\end{array}$ & $\begin{array}{c}\mathrm{S} \text { パターン } \\
\mathrm{n}=78\end{array}$ & $\mathrm{~F}$ 值 & $\mathrm{P}$ 値 \\
\hline 年齢 (歳) & $75.02 \pm 5.95$ & $74.92 \pm 6.82$ & $73.47 \pm 634$ & 112 & 033 \\
\hline BMI & $2415 \pm 4.01$ & $22.70 \pm 3.70$ & $2325 \pm 3.59$ & 1.68 & 019 \\
\hline 握力 $(k g)$ & $22.45 \pm 4.34$ & $22.03 \pm 4.40$ & $22.52 \pm 4.90$ & 017 & 084 \\
\hline 上体起こし (回) & $3.74 \pm 4.74$ & $5.04 \pm 4.50$ & $4.66 \pm 4.99$ & 0.78 & 0.46 \\
\hline 長座体前屈距離 $(\mathrm{cm})$ & $38.75 \pm 8.75$ & $37.02 \pm 7.66$ & $38.04 \pm 9.00$ & 0.45 & 0.64 \\
\hline 片足立ち保持時間(秒) & $37.02 \pm 39.74$ & $37.01 \pm 39.73$ & $34.82 \pm 36.35$ & 0.59 & 0.56 \\
\hline 6 分間歩行 $(m)$ & $421.98 \pm 78.65$ & $412.04 \pm 95.60$ & $426.92 \pm 7723$ & 0.40 & 0.67 \\
\hline 足把持力 (kg) & $5.06 \pm 2.36$ & $4.78 \pm 221$ & $5.72 \pm 280$ & 224 & 011 \\
\hline 大腿四頭筋筋力 ( kg) & $19.97 \pm 5.61$ & $19.04 \pm 513$ & $19.64 \pm 6.41$ & 029 & 0.75 \\
\hline 歩行時間 (秒) & $310 \pm 1.54$ & $2.71 \pm 0.63$ & $2.78 \pm 110$ & 1.45 & 024 \\
\hline TUG (秒) & $5.98 \pm 1.70$ & $580 \pm 123$ & $582 \pm 1.44$ & 017 & 084 \\
\hline
\end{tabular}

測定值はすべて平均値士 標準偏差を示す．

$\mathrm{P}$ パターン : plantigrade pattern, K パターン : half-kneeling pattern, S パターン : squatting pattern

BMI: Body Mass Index, TUG: Timed Up and Go test

$=0.78, \mathrm{p}=0.46)$, 長座体前屈距離 $(\mathrm{F}=0.45, \mathrm{p}=$ $0.64)$ ，片足立ち保持時間( $\mathrm{F}=0.59, \mathrm{p}=0.56) ， 6 \mathrm{MD}$ $(F=0.40, p=0.67)$, 足把持力 $(F=224, p=0$ 11), 大腿四頭筋筋力 $(F=029, p=0.75)$, 歩行時間 ( $F$ $=1.45, \mathrm{p}=0$ 24), TUG ( F=0 17, p=0 84) のいず れにも有意な群間差は認められなかった。

\section{N. 考 察}

本研究では, 女性高齢者における背臥位からの立ち 上がり動作パターンを分類し，各パターンごとの年齢， BMI，握力，上体起こし，長座体前屈距離，片足立ち 保持時間， $6 \mathrm{MD}$ ，足把持力，大腿四頭筋筋力，歩行 時間，TUGについて比較検討した。

本研究における背臥位からの立ち上がり動作を分類 した結果，S パターンが46 4\%，K パターンが29 2\%， P パターンが24 4\%であった。丸山 ${ }^{13)}$ は，健常成人 41 名を対象とし，立ち上がり動作における動作パターン と酸素消費量の関係を分析し, 立ち上がり動作パター ンの発達学的変化に沿って, エネルギー消費量が小さ くなることを報告している。すなわち，幼児期に獲得 される立ち上がり動作は, 年令の増加とともにPパ ターン, $\mathrm{K}$ パターン $\mathrm{S}$ パターンの順に変化していく ことから, より発達段階の高いS S パターンでエネル ギー消費量が小さいといえる。本対象例が $\mathrm{S}$ パター ン, $\mathrm{K}$ パターン, P パターンの順に多いことから，自 家用車や自転車，あるいは徒歩によって自ら調査に参 加できる程度に自立した女性高齢者では，健常成人と 同じようにエネルギー消費量の小さい S パターンを 行っている者が多いことが示された。

星ら ${ }^{10)}$ は，日常生活に影響を及ぼすような身体的・
精神的な既往および現病歴のない40代〜80代の健常者 126名を対象に，背臥位から立位への姿勢変換動作パ ターンを分析している。产の結果，高齡になるにした がい，発達段階の高いS パターンで立ち上がる動作 パターンは減少し, 逆に発達段階の低い $\mathrm{P}$ パターン で立ち上がる動作パターンが増加する傾向を示したと 報告している。しかし，本研究では $\mathrm{S}$ パターンで立 ち上がる者が最も多く，Pパターンで立ち上がる者が 最も少なかった。また, 各動作パターン別に分類した 3 群間と年齢を比較した結果，統計学的に有意差は認 められなかった。一般的に，筋力 ${ }^{19} や$ やバランス能力2021 は加齢とともに低下することが知られている。背臥位 からの立ち上がり動作は筋力やバランス能力などの 樣々な身体能力によって保障されると考えられること から，本被験者のように，自ら調査に参加できる程度 に自立した女性高齢者は, 背臥位からの立ち上がり動 作に必要な身体機能を十分に備えていたものと推察し た。

また, 本研究において各動作パターン別に分類した 3群と BMI を比較した結果, 統計学的な有意差は認 められなかった。梁川ら ${ }^{9}$ は, 健常成人 80 名を対象と し，BMI を平均值以上の群と平均值未満の群に分け て比較した結果，平均値以上の群で非対称的な立ち上 がりパターンを多く使用するとし，本研究とは異なる 結果を報告している。この理由として，梁川ら”が対 象とした対象者の BMI は21 $4 \pm 2$ 3であり，日本肥満 学会の定めた「普通 (18 5以上25.0未満)」のなかで も標準値である BMI22付近に位置しているが, 本研 究の対象者は, いずれの立ち上がり動作パターンにお いても標準値よりも高く (平均22 .70２4 15)，梁川 
らでいうところの平均值以上の群に属するため，有意 差か認められなかった可能性がある。また，対象者の 年齢の相違が考えられる。梁川らが対象としたのは $19.4 \pm 0.9$ 歳であり, 本研究の対象者は74 $2 \pm 6.4$ 歳で ある。加齢による身体機能の変化はこれまでに数多く

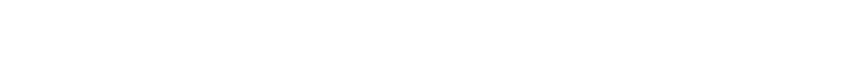
けた可能性が考えられる。

Shumway-Cook ら ${ }^{25}$ によると，運動とは個体，課題， 環境の3つの要因が相互作用することで発生するとさ れている。また, 個人にみられる運動の樣態やバリェー ションは課題や環境によって影響を受けるとされてお り, 個人が行う樣々な運動パターンは, 運動の目標が 付加されることで目標達成に必要な四肢の運動や方向 付けが決定されると報告している。さらに，帯刀 ${ }^{26)} は$ 背臥位から光の場で起立する条件と, 目的指向条件と して起立後 $2 \mathrm{~m}$ 先の目標へ歩く条件との比較を行って いる。弚の結果, 日常生活活動が自立し, 公共交通機 関を利用してデイケア通所が可能な要支援高齢者では， 目的指向動作に動作の集約化が認められたと報告して いる。本研究でも，測定条件をできるかぎり早く立ち 上がることとしたことで, 身体運動の自由度が高い女 性高齢者では, エネルギー消費量の小さい S パター ンでの立ち上がり動作に集約化が起きた可能性がある。 本研究では, 床からの立ち上がり動作パターンを類 型化し，各動作パターン別に分類した 3 群別に年齢， BMI, 各種身体機能を比較した結果, 全ての項目で統 計学的に有意な差は認められなかった。これらのこと より，女性高齢者による背臥位からの立ち上がり動作 パターンを規定する要因は, 年齢や体格, 筋力やバラ ンス能力といった身体機能ではなく，兴の他の要因， 例えば課題や環境による影響を受ける可能性が考えら れた。ただし, 本研究は町主催の健康支援事業に自ら 参加できる程度に自立した高齢者を対象とした。よっ て, 本研究を一般化するためには, 町主催の健康支援 事業に参加しない，および参加できない高齢者を対象 に調査し，身体機能との関係について検討する必要が あろう。また, 本研究は女性高齢者のみを対象とした ものである。今後, 今回の結果が男性にも適応できる のか否かについても検討する必要がある。

\section{引用文献}

1 ) 後藤由美, 横山一弥, 荒井未緒・他 : 脳卒中片麻瘏患者の 床からの立ち上がり動作に関係する機能およびAPDL へ の影響. 理学療法科学, 2001, 16(2): 5963 .
2 ) 西田宗幹, 植松光俊, 金澤寿久 - 他 : 脳卒中片麻痺の基本 動作能力の難易度順位について. 理学療法科学 , 1998,13 (2) : 7378 .

3 ) 小塩明子, 山中良二, 服部拓自 : 日本的生活樣式における リハビリテーションー 脳卒中片麻痺患者を中心に- . 総合 リハ, $1992,20(9): 829833$.

4 ) 井ノ上修一, 黑木場博幸, 林田友一・他: TKR 術後患者 の床 (畳) からの立ち上がりに動作について. 理学療法学, $1998,25(5)$ : 308317 .

5 ) Schaltenbrand G:The development of human motility and motor disturbances.Arch Neurol Psychiatry, 1928, 20: 720-730.

6 ) McGraw MB:The Neuromuscular Maturation of the Human Infant..Hafner,New York, 1962.

7 ) Milani-Comparetti A,Gidoni EA:Pattern analysis of motor development and of its disorders.Dev Med Child Neurol, 1967, 9: 625 -630 .

8 ) Milani-Comparetti A,Gidoni EA:Routine developmental examination in normal and retarded children.Dev Med Child Neurol, 1967, 9: 631-638.

9 ) 梁川和也, 吉田忠義, 藤澤宏幸 : 健常成人における背臥位 からの立ち上がりへの体格の影響. 東北理学療法学, 2010， $22: 1319$.

10) 星 文彦, 盛 雅彦, 内藤義則・他 : 健常高齢者の背臥位 からの立ち上がり動作- 動作パターンの推移について- . 総合リハ, $1990,18(1): 4550$.

11) 中村隆一, 齋藤 宏, 長崎 浩: 基礎運動学第 4 版, 医歯 薬出版, 東京, $1992, \mathrm{pp} 260288$.

12) VanSant AF:Rising from a supine position to erect stance Description of adult movement and a developmental hypothesisPhysical Therapy, 1988, 68(2): 185-192.

13) 丸山仁司：運動発達過程における動作出現順序と酸素消費 量. 埼玉医科大学雑誌, 1988, 15(2) : 97-109.

14) 文部科学省スポーツ・青年局 : 体力・運動能力調査報告書 . 文部科学省スポーツ・青年局, 東京, $2001, \mathrm{pp} 231-141$.

15) 村田 伸, 甲斐義浩, 田中真一・他 : ひずみゲージを用い た足把持力測定器の開発. 理学療法科学, 2006, 21(4) : 363367 .

16) 村田 伸, 忽那龍雄: 足把持力測定の試み. 理学療法科学, $2002,17(4): 243247$.

17) Podsiadlo D,Richardson S:The timed "Up \& Go"-a test of basic functional mobility for frail elderly persons-.J Am Geriatr Soc, 1991, 39: 142-148.

18) 島田裕之, 古名丈人, 大㴊修一・他 : 高齢者を対象とした 地域保健活動における Timed Up \& Go Test の有用性. 理学 療法学, 2006, 33: 105 111 .

19) Doherty TJ:Invited Review:Aging and sarcopenia.Journal of Applied Physiology, 2003, 95(4): 1717-1727.

20) Bohannon RW, Larkin PA, Cook AC et al: Decrease in timed balance test scores with aging.Physical Therapy, 1984, 64(7): 106770.

21) Choy NL, Brauer S, Nitz J: Changes in postural stability in women aged 20 to 80 years.Journal of Gerontology Series A: Biological Sciences and Medical Sciences, 2003, 58(6): 525-530.

22) Lauretani F,Russo CR, Bandinelli $S$ et al.: Age-associated 
changes in skeletal muscles and their effect on mobility: an operational diagnosis of sarcopenia.J Appl Physiol, 2003, 95(5): 1851-1860.

23) 鈴木政登, 石山育朗, 形本静夫 ·他 : 健康人の性・年齢別 最大酸素捸取量 $\left(\mathrm{VO}_{2} \max \right)$ の基準域および $\mathrm{VO}_{2} \max$ 判定 指標一 反復切断法による $\mathrm{VO}_{2} \max$ 基準域の設定一 . 体力科 学, 2003, 52(5) : 585 598 .

24) Steffen TM, Hacker TA, Mollinger L: Age-and gender-related test performance in community dwelling elderly people:sixminute walk test,Berg balance scale,timed up \& go test,and gait speeds.Phys Ther, 2002, 82(2): 128-137.

25) Shumway-Cook A,Woollacott MH:Motor control.Lippincott Williams \& Wilkins,Baltimore, 2007, pp 4-5.

26）帯刀隆之 : 目的指向型立ち上がり動作の解析による運動制 御の検討. 理学療法科学, 2009, 24(6) : 887- 893 . 